\title{
AMBULATORINIŲ PACIENTŲ SVEIKATOS RAŠTINGUMAS
}

\author{
Laimutė Kazlauskienė, Geriuldas Žiliukas, Sigutė Norkienė, Urtė Norkutė-Macijauskė \\ Klaipédos universitetas, Klaipédos jūrininku ligoninè
}

Raktažodžiai: sveikatos raštingumas, ambulatoriniai pacientai.

\begin{abstract}
Santrauka
Tyrimo tikslas. Išanalizuoti ambulatorinių pacientų sveikatos raštingumą.

Tyrimo metodika. Taikytas apklausos raštu metodas. Naudotas Europos sveikatos raštingumo (SR) klausimynas (HLS - EU-Q - 47). Tiriamaji kontingentą sudare 201 ambulatorinis pacientas 18 - 88 metu amžiaus. Duomenų analizè atlikta statistinių programų paketu „SPSS 17.0.1 for Windows“. Tyrimas atliktas laikantis etikos principų.

Rezultatai. Nustatyta, kad žemiausias ambulatorinių pacientų SR buvo sveikatos stiprinimo srityje, aukščiausias - sveikatos priežiūros srityje. Didžiausią itaką SR visose srityse ir aktualios sveikatos informacijos apdorojimo etapuose turejjo pacientų amžius ir išsilavinimas. Žemiausią SR turejo $70 \mathrm{~m}$. ir vyresni pacientai su pradiniu/pagrindiniu išsilavinimu. Ligu prevencijos srityje moterų SR buvo aukštesnis nei vyrų, sveikatos priežiūros srityje - mieste gyvenančių pacientų. Informacijos gavimas, supratimas, ịvertinimas ir pritaikymas reikšmingai blogesnis buvo 70 $\mathrm{m}$. ir vyresnių - reikšmingai geresnis aukštesniojo ir aukštojo išsilavinimo pacientų. Tarp vyrų ir moterų informacijos gavimas, ịvertinimas ir pritaikymas nesiskyre, tik informacijos supratimas moterų buvo reikšmingai geresnis nei vyrų.

Išvada. Pacientų SR didžiausią įtaką turi amžius, išsilavinimas ir lytis. Siekiant pagerinti gyventoju sveikatos raštingumą, edukacinius metodus reikètų taikyti visais gyvenimo periodais, atsižvelgiant ị demografinius duomenis.
\end{abstract}

\section{Ivadas}

Sveikatos koncepcijai skiriama vis daugiau dèmesio, tačiau informacijos apie sveikatos raštingumo (SR) būklę Europoje vis dar trūksta. SR yra susijęs su žmonių gebejjimu patenkinti sveikatos poreikius šiuolaikinèje visuomenejje
[14]. Daugejjant sveikatos informacijai, svarbu gebėti ne tik ją gauti, bet ir suprasti, ivertinti bei pritaikyti. Teisingiems sprendimams priimti reikalingi kognityviniai igūdžiai ir patikimi informacijos šaltiniai [15]. Esminiai kognityviniai, fiziniai, emociniai vystymosi procesai vyksta vaikysteje ir jaunystèje, todèl su sveikata susijusios elgsenos ir igūdžių ugdymą svarbu pradèti kuo jaunesnio amžiaus [1]. Tyrimų rezultatai rodo, kad maždaug pusė Europos ir Jungtinių Amerikos Valstijų (JAV) gyventojų pasižymi žemu SR, sunkiai randa ir pritaiko sveikatos informaciją, todèl negali priimti informuotumu pagristų sprendimų [13]. Žemo SR pacientai yra prastesnès sveikatos, dažniau gydosi stacionare, rečiau laikosi paskirto gydymo nurodymų, dažniau patiria vaistų vartojimo klaidų, mažiau naudojasi ligų profilaktikos priemonèmis $[11,12]$. Žemesnis SR lemia ne tik blogesnę sveikatos būklę, neigiamus gydymo rezultatus, bet ir didesnį sveikatos priežiūros (SP) paslaugų poreikị. Aukštesnio SR asmenys, lyginant su žemesnio SR, yra reiklesni sveikatos informacijai, dažniau naudojasi sveikatos informaciniais šaltiniais [15, $5,12,17]$. Itaką sveikatai darantys veiksniai pasireiškia ir per socialinius, ekonominius, demografinius pokyčius, kurie veikia šeimą, kultūrą, darbo sąlygas, mokymosi aplinką ir socialinę bendruomenès struktūrą [8]. Tyrimų rezultatai rodo, jog SR koreliuoja su išsilavinimu, tačiau nemaža dalis išsilavinusių žmonių yra žemo SR, nesilaiko sveikos gyvensenos principų, mažai juda, turi žalingų ịpročių, sveikatai išsaugoti skiria mažai dèmesio. Pastaruoju metu pasaulyje stebimas didesnis susidomejjimas SR tema. Atsižvelgiant ị greitą technologijų raidą JAV, pradèti pirmieji moksliniai tyrimai, kaip SR susijęs su sveikatos informacinių tecnologijų prièmimu ir naudojimu, elektroninès sveikatos portalų tinkamumu ir poreikiu žemą SR turintiems pacientams. Lietuvoje atlikta daug tyrimų, analizuojančių žmonių gyvensenos ypatumus, tačiau SR reikšmẻ kol kas mažai tyrinèta sritis [15].

Tyrimo tikslas: išanalizuoti ambulatorinių pacientų sveikatos raštingumą.

\section{Tyrimo medžiaga ir metodai}

Daugiau nei puse (52,2 proc.) tiriamujų buvo 30-54 metų, 30,3 proc. $-55-69$ metų, 8,5 proc. $-18-29$ metų ir 9,0 proc. - 
70 metų ir vyresni. Pagal išsilavinimą dauguma (41,8 proc.) tiriamųjų turèjo aukštaji, 22,9 proc. - aukštesniji, 29,9 proc. - vidurinị/spec.vidurinị ir 5,5 proc. - pradinị/pagrindinị. Didžioji dauguma (78,6 proc.) tiriamujų buvo miesto, 10,0 proc. - mažesnių miestelių ir 11,4 proc. - kaimo gyventojai. Darbe pagal gyvenamają vietą buvo analizuojamos dvi grupès: $158(78,6$ proc.) tiriamieji gyvenantys miestuose ir 43(21,4 proc.) - miesteliuose ir kaimo vietovèse. Pagal socialinę padètį daugumą ( 72,1 proc.) sudarè dirbantys asmenys, 15,9 proc. tiriamuju buvo pensininkai, 6,0 proc - - bedarbiai, 2,0 proc. - moksleiviai/studentai ir 4,0 proc. - kiti (nurodè neigalumą). Pagal socialinę padètį darbe buvo analizuojamos dvi grupès - $145(72,1$ proc.) dirbantys ir 56(27,9 proc.) nedirbantys. Pagal šeiminę padètį dauguma $(65,7$ proc.) tiriamujų buvo vedę/ištekejjusios, 7,0 proc. - gyveno nesusituokę, 10,9 proc. - buvo nevedę/netekejjusios, 8,5 proc. - išsiskyrę/išsituokusios ir 8,0 proc. - našliai/našlès. Pagal šeiminę padètị buvo analizuojamos dvi tiriamujų grupès 146 (72,6 proc.) gyvenantys su partneriu/-e ir 55 (27,4 proc.) vieniši. Siekiant ịvertinti ambulatorinių pacientų SR buvo taikomas kiekybinis tyrimas, naudojant anketinès apklausos raštu metodą. Tyrimo anketa sudaryta remiantis Europos SR klausimynu (HLS - EU-Q - 47). SR vertintas pagal tris sritis (duomenus): sveikatos priežiūros, ligų prevencijos, sveikatos stiprinimo ir keturis aktualios informacijos apdorojimo etapus: gauti, suprasti, įvertinti ir pritaikyti [5]. Gautų duomenų analizė atlikta statistiniu programų paketu „SPSS 17.0.1 for Windows". Buvo apskaičiuoti visų SR sričių indeksai, kurie galëjo igyti reikšmes nuo 0 iki 50 balų, kur didesnis skaičius reiškè aukštesni SR. Bendro SR indeksas buvo (30,2 $\pm 6,0$ balų); SR sveikatos priežiūros srityje - (32,2 $\pm 6,3$ balų); ligų prevencijos - (31,2 $\pm 6,7$ balu) ; ir sveikatos stiprinimo - (27,4 $\pm 7,1$ balų). Taip pat buvo apskaičiuoti aktualios informacijos apdorojimo etapų indeksai - gavimo $(29,4 \pm 7,5$ balų), supratimo $(32,8 \pm 6,5$ balų), ìvertinimo $(30,1 \pm 6,7$ balų) ir pritaikymo (28,8 $\pm 6,1$ balų). Analizuojant koreliacinius imties požymių ryšius naudotas Pirsono (Pearson) (r) koreliacijos metodas. Naudoti statistinių hipotezių reikšmingumo lygmenys: kai $p<0,05$ - reikšminga $\left(^{*}\right)$; kai $p<0,01$ - labai reikšminga $(* *)$; kai $<<0,001$ - itin reikšminga $(* * *)$ ir kai $\mathrm{p}>0,05$ (ns) - statistiškai nereikšminga. Klausimyno vidinis patikimumas vertintas apskaičiavus Kronbacho (Cronbach) alfa. Tyrimas atliktas laikantis etikos principų.

\section{Tyrimo rezultatai}

Vertinant ambulatorinių pacientų sveikatos raštingumą pagal sritis nustatyta, kad tiriamieji reikšmingai $(\mathrm{p}<0,01)$ geriausiai savo SR vertino SP srityje, blogiausiai - sveikatos stiprinimo srityje $(\mathrm{p}<0,001)(1 \mathrm{pav}$.).

Sveikatos priežiūros srityje didžiajai daugumai tiriamųjų buvo lengva (labai lengva/lengva) suprasti gydytojo/vaistininko nurodymus, kaip vartoti paskirtus vaistus ( 86,1 proc.), laikytis gydytojo/vaistininko (84,6 proc.) ir vaistų instrukcijos $(83,1$ proc.) nurodymų, iškviesti greitają medicinos pagalbą ( 79,1 proc.), sužinoti, kur kreiptis profesionalios pagalbos susirgus ( 72,1 proc.), suprasti, ką sako gydytojas (69,6 proc.) ir vaistų instrukcijos (pakuotès lapelio) turini (69,6 proc.). Daugiau nei pusei tiriamujų buvo lengva (labai lengva/lengva) sužinoti, ką reikia daryti prireikus skubios medicinos pagalbos (62,1 proc.), rasti informacijos apie juos dominančios ligos simptomus (60,7 proc.), pasinaudoti gydytojo suteikta informacija priimant sprendimus, susijusius su jų liga (60,7 proc.), ivvertinti gydytojo pateiktos informacijos tinkamumą (57,3 proc.) Sunkiausiai buvo ịvertinti, ar žiniasklaidoje pateikta informacija apie ligas yra patikima (labai lengva/lengva 23,9 proc., nebuvo ịsitikinę 44,8 proc., sunku/labai sunku 31,4 proc.), îvertinti ịvairių gydymo būdų

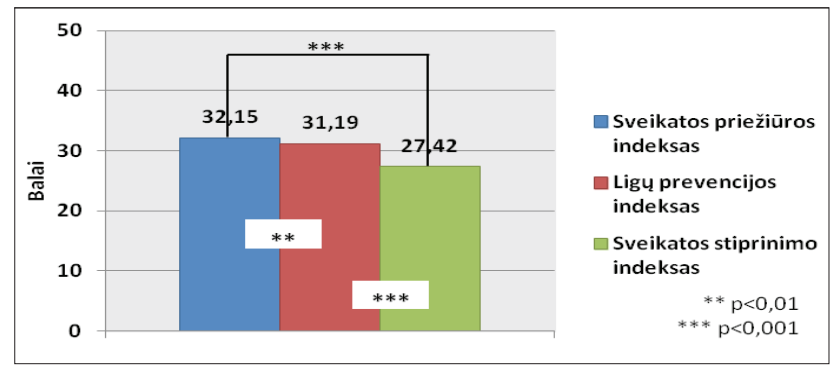

1 paveikslas. Ambulatorinių pacientų sveikatos raštingumas pagal sritis.

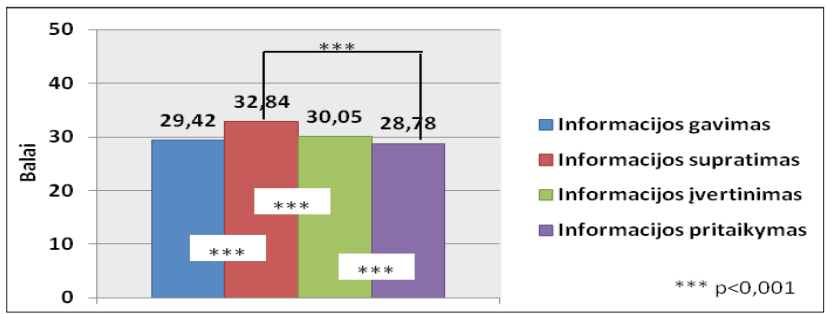

2 paveikslas. Sveikatos raštingumas aktualios sveikatos informacijos apdorojimas etapuose.

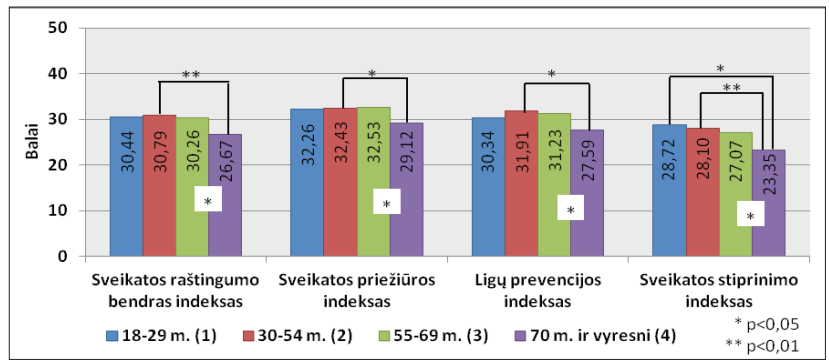

3 paveikslas. Ambulatorinių pacientų sveikatos raštingumas pagal amžių. 
privalumus ir trūkumus (labai lengva/lengva 31,9 proc., nebuvo ịsitikinę 45,8 proc., sunku/labai sunku 22,4 proc.), suprasti, ką reikia daryti teikiant skubią medicinos pagalbą (labai lengva/lengva 36,3 proc., nebuvo įsitikinę 44,3 proc., sunku/labai sunku 19,4 proc.). Ivertinti, kada reikalinga kito gydytojo nuomone, lengva (labai lengva/lengva) buvo 43,3 proc. tiriamujų, 38,8 proc. - vidutiniškai (nèra tikri) ir 17,9 proc. - sunku (sunku/labai sunku). Rasti informacijos apie dominančios ligos gydymą lengva (labai lengva/lengva) buvo maždaug pusei (49,3 proc.) tiriamujų, 31,3 proc., - vidutiniškai (nèra tikri) ir 19,4 proc. - sunku (sunku/labai sunku).

Ligų prevencijos srityje didžiajai daugumai tiriamųų buvo lengva (labai lengva/lengva) suprasti, kodèl reikia tikrintis sveikatą ( 90,5 proc.), suprasti ịspejjamuosius užrašus apie rūkymo, mažo fizinio aktyvumo, alkoholio vartojimo žalą sveikatai ( 88,1 proc.), ịvertinti įspejjamujjų užrašų apie rūkymo, mažo fizinio aktyvumo, alkoholio žalos sveikatai teisingumą ( 83,1 proc.). Dauguma tiriamųjų lengvai (labai lengva/lengva) rado informacijos, kaip pakeisti savo nesveiką elgseną (mesti rūkyti, padidinti fizinị aktyvumą, su-

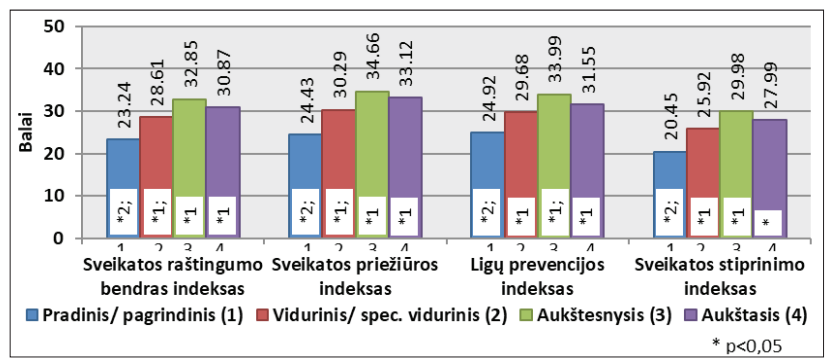

4 paveikslas. Sveikatos raštingumas pagal pacientų išsilavinimą.

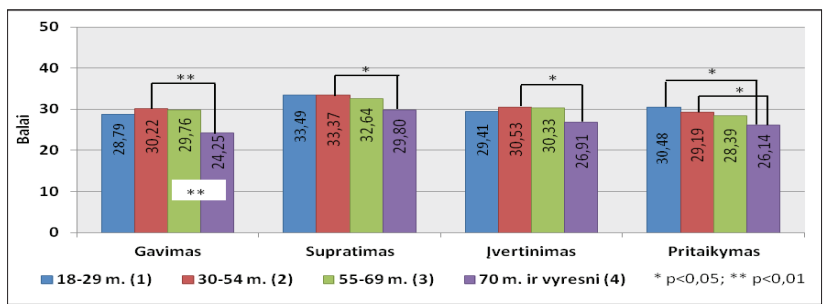

5 paveikslas. Sveikatos raštingumas aktualios informacijos apdorojimo etapuose pagal amžių.

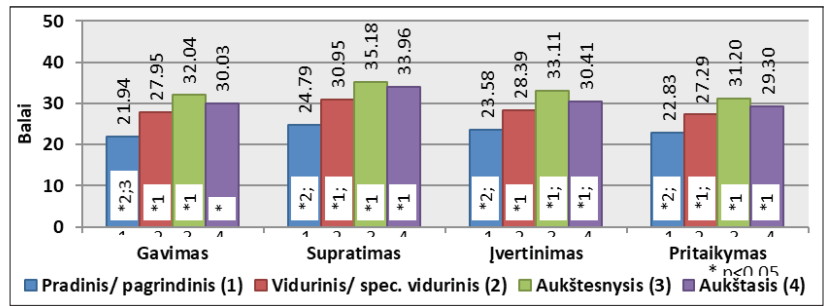

6 paveikslas. Aktualios informacijos apdorojimas etapuose pagal išsilavinimą. mažinti alkoholio vartojimą) $(69,1$ proc.) ir kaip kontroliuoti antsvorị, padidejusị kraujo spaudimą ar cholesterolio kiekị kraujyje (64,6 proc.), suprasti, kodèl reikia pasiskiepyti $(69,1$ proc.). Sunkiausia buvo nuspręsti, kokių skiepų jiems reikia (labai lengva/lengva 27,4 proc., nebuvo tikri 44,3 proc., sunku/labai sunku 28,4 proc.) ir kaip apsisaugoti nuo ligų, remiantis žiniasklaidos informacija (labai lengva/lengva 30,4 proc., nebuvo tikri 46,8 proc., sunku/labai sunku 22,9 proc.), ivvertinti žiniasklaidos pateikiamos informacijos apie pavojų sveikatai teisingumą (labai lengva/lengva 38,8 proc., nebuvo tikri 39,8 proc., sunku/labai sunku 21,4 proc.). Šiek tiek daugiau nei pusei tiriamujų buvo lengva (labai lengva/ lengva) apsispręsti eiti pas gydytoją pasitikrinti sveikatos (57,7 proc.), vidutiniškai (nebuvo tikri) - 18,9 proc. ir sunku (labai sunku/sunku ) - 23,4 proc. tiriamuju . Rasti informacijos apie reikalingus skiepus ir sveikatos patikros tyrimus bei kaip kontroliuoti psichikos sveikatos problemas, tokias kaip stresas ar depresija, lengva (labai lengva/lengva) buvo atitinkamai 47,3 proc. ir 46,3 proc. tiriamujų, vidutiniškai (nebuvo tikri) - atitinkamai 31,8 proc. ir 28,9 proc., sunku (labai sunku/sunku) - atitinkamai 20,9 proc. ir 27,9 proc. tiriamųų. Apsispręsti pasiskiepyti nuo gripo lengva (labai lengva/lengva) buvo 41,3 proc. tiriamuju, nebuvo tikri - 30,8 proc. ir sunku (labai sunku/sunku) - 27,9 proc. tiriamųų. Nuspręsti, kaip apsisaugoti nuo ligų, remiantis šeimos narių ir draugu patarimais bei kokio sveikatos patikrinimo reikia lengva (labai lengva/lengva) buvo po 40,3 proc. tiriamųu, nebuvo tikri - atitinkamai 39,8 proc. ir 42.3 proc. tiriamuju, sunku (labai sunku/sunku) -atitinkamai 19,9 proc. ir 17,4 proc. tiriamujų.

Sveikatos stiprinimo srityje daugumai tiriamujų lengva (labai lengva/lengva) buvo rasti informacijos apie sveikatos stiprinimą (75,6 proc.). Daugiau nei pusei tiriamujų buvo lengva (labai lengva/lengva) ịvertinti, kaip jų gyvenimas daro įtaką jų sveikatai ir gerovei $(69,2$ proc.) bei ar kasdienis elgesys turi įtakos jų sveikatai (68,6 proc.), išsiaiškinti, kaip jų gyvenimo sąlygos padeda jiems išlikti sveikiems (63,7 proc.), suprasti šeimos narių ar draugų teikiamus sveikatos patarimus (59,7 proc.) bei žiniasklaidoje pateikiamą informaciją apie tai, kaip tapti sveikesniam (51,3 proc.). Sunkiausia buvo pakeisti gyvenimo sąlygas, kurios įtakios jų sveikatai ir gerovei (labai lengva/lengva 19,3 proc., nebuvo tikri 31,3 proc. ir labai sunku/sunku 49,3 proc.), užsinorèjus pradèti mankštintis ar lankyti sporto klubą (labai lengva/ lengva 29,4 proc., nebuvo tikri 21,9 proc. ir labai sunku/ sunku 48,8 proc.), dalyvauti bendruomenès sveikatos stiprinimo renginiuose (labai lengva/lengva 22,4 proc., nebuvo tikri 33,8 proc. ir labai sunku/sunku 43,7 proc.), pastebèti pastangas, skirtas stiprinti jų sveikatą darbe (labai lengva/ lengva 25,4 proc., nebuvo tikri 32,3 proc. ir labai sunku/ 
sunku 42,3 proc.), suprasti sveikatai įtaką darančius politinius sprendimus (labai lengva/lengva 21,9 proc., nebuvo tikri 37,8 proc. ir labai sunku/sunku 40,3 proc.) ( 8 pav.). Rasti informacijos apie psichikos sveikatos stiprinimą bei apie sveikatai palankesnę kaimynystę lengva (labai lengva/ lengva) buvo atitinkamai 38,3 proc. ir 26,4 proc. tiriamujų, nebuvo tikri, kad tai lengva - atitinkamai 36,8 proc. ir 50,2 proc., sunku (labai sunku/sunku) - atitinkamai 24,9 proc. ir 23,4 proc. tiriamujų. Suprasti maisto pakuotèse pateikiamą informaciją lengva (labai lengva/lengva) buvo 41,8 proc. tiriamujų, vidutiniškai (nebuvo tikri) - 25,4 proc. ir sunku (labai sunku/sunku) 32,9 proc. tiriamujų. Priimti sprendimus, susijusius su jų sveikatos stiprinimu, lengva (labai lengva/ lengva) buvo 46,8 proc. tiriamujų, vidutiniškai (nebuvo tikri) $-27,4$ proc. ir sunku (labai sunku/sunku) - 25,9 proc. tiriamujųu. Suprasti informaciją, kaip išlaikyti aiškų mąstymą, lengva (labai lengva/lengva) buvo 46,3 proc. tiriamujų, vidutiniškai (nebuvo tikri) - 34,3 proc. ir sunku (labai sunku/ sunku) - 19,4 proc. tiriamujų.

Aktualios informacijos apdorojimo etapuose tiriamieji žymiai $(\mathrm{p}<0,001)$ geriau vertino informacijos supratimą nei jos gavimą, ịvertinimą ir pritaikymą. Informacijos pritaikymą žymiai $(p<0,001)$ blogiau nei supratimą ir ịvertinumą (2 pav.).

Sociodemografinių duomenų ịtakos SR analizès metu nustatyta, kad bendras SR ir SR sveikatos priežiūros ir ligu prevencijos srityse buvo žymiai blogesnis 70 metų ir vyresnių tiriamujų nei 30-54 metų ir 55-69 metų. Tuo tarpu SR tarp kitų amžiaus grupių reikšmingai nesiskyrè (3 pav.).

Bendro SR ir SR visose srityse vertinimas itin reikšmingai $(p<0,001)$ priklausė nuo tiriamujų išsilavinimo - esant žemesniam išsilavinimui buvo žemesnis ir SR. Tiriamuju su aukštesniuoju ir aukštuoju išsilavinimu SR reikšmingai nesiskyrè, tik aukštesnis buvo tiriamųjų su aukštesniuoju išsilavinimu (4 pav.).

Lytis įtakos turejo tik ligų prevencijos srityje - moteru SR buvo žymiai aukštesnis nei vyrų. Bendras SR ir SR kitose srityse tarp vyrų ir moterų reikšmingai nesiskyrè. Pagal darbinę padètị nustatytas reikšmingas SR skirtumas tik ligų prevencijos srityje - SR buvo žymiai aukštesnis dirbančiujų tiriamųų nei nedirbančiujų. Pagal gyvenamą vietą nustatytas reikšmingas skirtumas tik SP srityje - SR buvo žymiai aukštesnis tiriamujjų gyvenančių mieste nei miesteliuoe/kaimuose. Pagal šeiminę padètį reikšmingų skirtumų nenustatyta. Aktualios informacijos apdorojimo etapuose, informacijos gavimo, supratimo ir įvertinimo vertinimas buvo reikšmingai žemesnis 70 metų ir vyresnių tiriamǔjų, nei 30-54 metų Informacijos pritaikymo vertinimas reikšmingai žemesnis buvo 70 metų ir vyresnių tiriamujų grupejje, nei 18-29 metų ir 30-54 metų grupèse. Tarp kitų amžiaus grupių informacijos vertinimas informacijos apdorojimo etapuose reikšmingai nesiskyrè (6 pav).

Pagal išsilavinimą reikšmingai aukščiausias vertinimas, visuose aktualios sveikatos informacijos apdorojimo etapuose, buvo tiriamujų su aukštesniuoju išsilavinimu grupejje lyginant su žemesnio išsilavinimo grupèmis. Informacijos gavimo vertinimas tarp tiriamųjų su aukštesniuoju ir aukštuoju išsilavinimu reikšmingai nesiskyrè, tik stebėta, kad aukštesnis buvo su aukštesniuoju išsilavinimu. (6 pav.).

Moterų informacijos supratimo vertinimas buvo žymiai aukštesnis nei vyrų. Kituose informacijos apdorojimo etapuose reikšmingų skirtumų nenustatyta. Aktualios informacijos gavimo, supratimo, ivvertinimo ir pritaikymo vertinimai priklausomai nuo gyvenamosios vietos reikšmingai nesiskyrè, tik stebėti šiek tiek aukštesni mieste gyvenančių pacientų. Informacijos apdorojimas etapuose priklausomai nuo tiriamujjų darbinès ir šeiminès padèties reikšmingai nesiskyrè.

\section{Rezultatų aptarimas}

Analizuojant ambulatorinių pacientų SR pagal sritis ir aktualios sveikatos informacijos apdorojimo etapus, buvo vertinama ir sociodemografinių duomenų įtaka SR. Nustatyta jog daugumos pacientų SR visose srityse buvo vidutinis. Panašūs rezultatai gauti ir kitu tyrèjų: Europoje, Lietuvoje $[4,16,14,11]$, Brazilijoje, JAV nustatyta, jog beveik pusė vyrenio amžiaus asmenų yra nepakankamo SR, vyresnio amžiaus, žemesnio išsilavinimo, nedirbantiems respondentams sudètingiau suprasti informaciją apie sveikatos stiprinimą ir ligų prevenciją $[2,3,12,4]$. Pacientams sunku kontroliuoti psichikos sveikatos problemas, tokias kaip streso poveikis ar depresija. Gauti rezultatai atspindi blogejjančią gyventoju psichinę sveikatą. PSO duomenimis, beveik 11 proc. Europos Sajungos gyventojų turi psichikos sveikatos sutrikimų. Trečdalis pagyvenusių žmonių, sergančiųjų išemine širdies liga, serga lengva, ketvirtadalis - vidutiniškai sunkia, 11 proc. - sunkia depresijos forma ir tik 15 proc. tiriamujų depresija neserga [9]. Beveik pusè pacientų patiria psichologinę ịtampą ir stresą, tačiau nesikreipia pagalbos ị psichologus [10]. Iš darbe analizuotų demografinių duomenų didžiausių įtaką SR visose srityse turejo pacientų amžius ir išsilavinimas. Žemiausias SR buvo 70 metų ir vyresnių su pradiniu/pagrindiniu išsilavinimu pacientų. Moterų SR buvo aukštesnis ligų prevencijos srityje ir aktualios informacijos supratimo etape. Anksčiau Europoje atliktų tyrimų duomenimis, didžiausią ịtaką SR turèjo finansinis nepriteklius, socialinė padètis, išsilavinimas, amžius ir lytis $[16,5,14]$.

\section{Išvados}

1. Ambulatoriniai pacientai savo sveikatos raštingumą geriausiai vertino sveikatos priežiūros srityje, lyginant su ligu 
prevencijos $(\mathrm{p}<0,01)$, su sveikatos stiprinimo - $(\mathrm{p}<0,001)$. Blogiausiai sveikatos stiprinimo, lyginant su kitomis sritimis. Aktualios informacijos apdorojimo etapuose - informacijos supratimas buvo geresnis nei jos gavimas, ivertinimas ir pritaikymas, informacijos pritaikymas buvo blogesnis, nei jos supratimas ir ịvertinimas.

2. Didžiausią įtaką sveikatos raštingumui turejo pacientų amžius ir išsilavinimas. Žemiausią sveikatos raštingumą visose srityse turejjo $70 \mathrm{~m}$. ir vyresni pacientai, ir su pradiniu/ pagrindiniu išsilavinimu. Sveikatos raštingumas ligų prevencijos srityje aukštesnis buvo moterų, sveikatos priežiūros srityje - mieste gyvenančių pacientų.

3. Aktualios sveikatos informacijos apdorojimui etapuose didžiausią įtaką turèjo pacientų amžius ir išsilavinimas. Informacijos gavimas, supratimas, įvertinimas ir pritaikymas reikšmingai blogesnis buvo $70 \mathrm{~m}$. ir vyresnių, reikšmingai geresnis aukštesniojo ir aukštojo išsilavinimo pacientų. Tarp vyrų ir moterų informacijos gavimas, ịvertinimas ir pritaikymas nesiskyre, tik informacijos supratimas moterų buvo reikšmingai geresnis, nei vyrų.

4. Siekiant pagerinti gyventojų sveikatos raštingumą, edukacinius metodus reikètų taikyti visais gyvenimo periodais, atsižvelgiant ị demografinius duomenis: amžių, išsilavinimą, lytị, darbinę bei šeiminę padètį.

\section{Literatūra}

1. Bröder J, Okan O, Bauer U, Bruland D, Schlupp S, Bollweg TM, Saboga-Nunes L, Bond E, Sørensen K, Bitzer EM, Jordan S, Domanska O, Firnges C, Carvalho GS, Bittlingmayer UH, Levin-Zamir D, Pelikan J, Sahrai D, Lenz A, Wahl P, Thomas M, Kessl F, Pinheiro P. Health literacy in childhood and youth: systematic review of definitions and models. BMC Public Health 2017 Apr 26;17(1):361. doi: 10.1186/s12889-017-4267-y. Erratum in:BMC Public Health. 2017 May 9;17 (1):419

https://doi.org/10.1186/s12889-017-4267-y

2. Carthery-Goulart MT, Anghinah R, Areza-Fegyveres R, Bahia VS, Brucki SMD, Damin A. et al. Performance of a Brazilian population on the testo functional health literacy in adults. Rev Saude Publica; 2009; 43(4):631-638.

https://doi.org/10.1590/S0034-89102009005000031

3. Eichler, Wieser, Brügger. 2009. The costs of limited health literacy prieiga per internetą: https://www.ncbi.nlm.nih.gov/ pubmed/19644651

4. Javtokas Z. Lietuvos gyventojų sveikatos raštingumo tyrimo duomenų apžvalga. LR SAM Sveikatos mokymo ir ligų centras. Vilniaus universiteto medicinos fakulteto visuomenès sveikatos institutas. Vilnius, 2012.

5. Javtokas Z., Sabaliauskas R. ir kt. Suaugusių Lietuvos gyventojų sveikatos raštingumas. Visuomenès sveikata, 2013; 4(63).

6. Javtokas Z., Žagminas K. Gyventojų sveikatos raštingumo vertinimas. Metodiniai patarimai. Sveikatos mokymo ir ligų prevencijos centras, Vilniaus universiteto Medicinos fakulteto Sveikatos mokslų institutas, 2017.

7. Javtokas, Z. Salutogenezès modelio panaudojimas mokinių sveikatai stiprinti. Informacinis metodinis leidinys. Vilnius, 2007; $5-6$.

8. Javtokas Z., Sveikatos stiprinimo konspektas, 2009. Publikuota internete: http://vasc.sam.lt/lektūra.

9. Jotkuvienė I., Vasyliūtė I., Žiliukas G. Pagyvenusių žmonių, sergančių išemine širdies liga, su sveikata susijusi gyvenimo kokybè. Reabilitacijos metodų ir priemonių efektyvumas. Kaunas, 2017.

10. Kazlauskienė L., Mockienė V., Žiliukas G. Išeminės širdies ligos rizikos veiksniai, išaiškejję ambulatorinès konsultacijos metu. Reabilitacijos metodų ir priemonių efektyvumas. Kaunas, 2017.

11. Lin V, Pettersson B, Brink E, David A, Agarwal SA. Primer for mainstreaming health promotion. The 7th Global Conference on Health Promotion, "Promoting Health and Development: Closing the Implementation Gap". Conference working draft. WHO, 2009.

12. Mackert M, Mabry-Flynn A, Champlin S, Donovan EE, Pounders K. Health literacy and health information technology adoption: the potential for a new digital divide. J Med Internet Res 2016; 18(10):e264.

https://doi.org/10.2196/jmir.6349

13. Rowlands G, Protheroe J, Richardson M, Seed P, Winkley J, Rudd R. The health information gap: the mismatch between population health literacy and the complexity of health information; an observational study. British Journal of General Practice 2015; 65 e379-e386.

https://doi.org/10.3399/bjgp15X685285

14. Sørensen K, Pelikan JM, Röthlin F, Ganahl K, Slonska Z, Doyle G, Brand H. Health literacy in Europe: comparative results of the European health literacy survey (HLS-EU). The European Journal of Public Health 2015; 25(6), 1053-1058. https://doi.org/10.1093/eurpub/ckv043

15. Zagurskienė D., Misevičienė I. Skirtingų sveikatos raštingumo lygių pacientų nuomonė apie slaugytojų teikiamą sveikatos informaciją. Kaunas. Medicina, 2010; 46(1):27-34.

16. Zagurskienė D. Pacientų sveikatos raštingumo vertinimas. Daktaro disertacija. Biomedicinos mokslai. Kaunas, 2009.

17. Zide M, Caswell K, Peterson E, Aberle DR, Bui AA, Arnold CW Consumers. Patient Portal Preferences and Health Literacy: A Survey Using Crowdsourcing JMIR Res Protoc 2016; 5(2):e104.

https://doi.org/10.2196/resprot.5122

\section{HEALTH LITERACY OF AMBULATORY PATIENTS L.Kazlauskienė, G.Žiliukas, S.Norkienė, U.Norkutè-Macijauskè}

Key words: health literacy, ambulatory patients. 


\section{4}

\section{Summary}

The aim. To analyze the health literacy of ambulatory patients. Investigation Methodology. The method of questionnaire was applied. The European Health Literacy Survey (HLS) questionnaire was used (HLS - EU-Q - 47). The target contingent was 201 ambulatory patients age 18-88. Data analysis performed by statistical software package "SPSS 17.0.1 for Windows". The study was conducted in accordance with ethical principles.

Results. It was determined that the lowest ambulatory patients HLS was in the field of health promotion, the highest in the field of health care. The patient's age and education was the most influential factors processing the relevant health information and in all HLS areas. The lowest HLS was of the 70 years and older patients with primary/secondary education. In the area of disease prevention, the women HLS was higher than men, and in the area of he- althcare - the urban populations. The reception, understanding, assessment and application of information was significantly lower by the patients age 70 and older - significantly better for higher education patients. There was no difference between men and women in obtaining, evaluating and applying information, just women understanding of information was significantly better than men.

Conclusion. The patient's HLS is most affected by age, education and sex. In order to improve the health of the population, educational methods should be applied throughout the life span, taking into account demographic data.

Correspondence to: kazlauskiene.laimute@gmail.com

Gauta 2018-11-26 